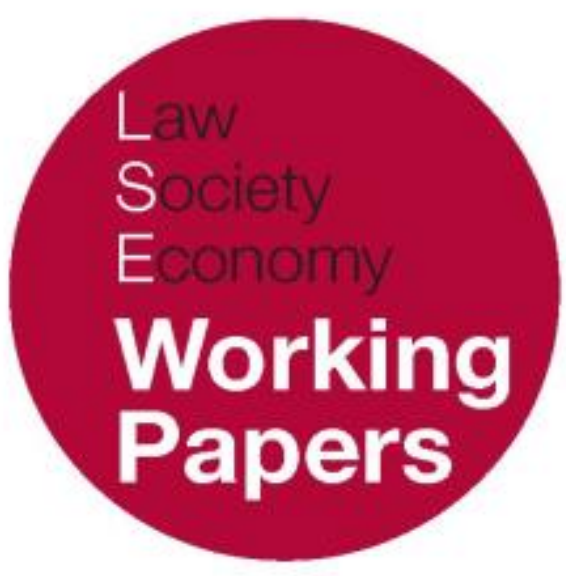

\title{
Stewardship and Collateral
}

\author{
Joanna Benjamin \\ LSE Law, Society and Economy Working Papers 7/2017 \\ London School of Economics and Political Science \\ Law Department
}

This paper can be downloaded without charge from LSE Law, Society and Economy Working Papers at: www.lse.ac.uk/collections/law/wps/wps.htm and the Social Sciences Research Network electronic library at: https://papers.ssrn.com/sol3/papers.cfm?abstract_id=2969829. (C) Joanna Benjamin. Users may download and/or print one copy to facilitate their private study or for non-commercial research. Users may not engage in further distribution of this material or use it for any profit-making activities or any other form of commercial gain. 


\title{
Stewardship and Collateral
}

\author{
Joanna Benjamin *
}

\begin{abstract}
Recent case law has confirmed that investors in indirectly held securities are not recognised as shareholders or bondholders, and are thus disenfranchised. This cuts across calls for greater investor activism. Further, the post-crisis emphasis on financial market collateral promotes operational changes running counter to enfranchisement and activism. The suggested solution is to recognise two categories of holding, namely traditional securities and collateral depositary receipts.
\end{abstract}

${ }^{*}$ Emeritus Professor, Department of Law, London School of Economics and Political Science. 


\section{INTRODUCTION}

Recent case law has confirmed that, under English law, investors in indirectly held securities are not holders of the underlying shares or bonds, and accordingly cannot enforce the rights of shareholders or bondholders against the issuer. This disenfranchisement of investors is a problem that has attracted an active debate amongst distinguished commentators. ${ }^{1}$ Both legal and operational solutions are being sought and offered. This discussion turns to another dimension of the problem, namely the commercial pressures that tend to separate investors from their entitlements.

These pressures are associated with the ascendant phenomenon of securities finance, whereby the purpose of more and more long securities positions is not investment, but collateral. The interests of investors and those of collateral takers differ and sometimes conflict. Investors want stable and certain relations with issuers. But the operational changes that have separated investors from entitlements have served the interests of collateral takers in the short-term securities finance markets, in which client securities are used and reused, by promoting liquidity and certain enforcement rights for the collateral taker. This in turn secures the supply of cheap credit.

Two major wholesale market trends will increase the role of securities finance for the foreseeable future. One is the post-crisis regulatory emphasis on the collateralisation of position exposures, by infrastructures and firms alike. The other is the tendency of the tougher post-crisis regulation of traditional banking to divert short-term borrowers into the repo and cash-driven securities lending markets for cheap credit.

A long positon in securities collateral does not function as a mutual relationship between position holder and issuer, with votes and other entitlements being exchanged for capital and stewardship. Rather, securities collateral functions as a reified, fleetingly-held medium of exchange. It has become so central to wholesale market liquidity that ICMA told us, in 2014, that collateral is the new cash. $^{2}$ An ever-larger proportion of the institutional asset base is circulating, in functional effect, as money. The historic significance of this development is equal to the transition from the bullion held by goldsmiths to cash at bank.

No legal or operational solution to re-enfranchise investors will take hold unless the conflict between investors and collateral takers is resolved.

1 In particular, Professor Eva Micheler of the London School of Economics has been active in promoting the issue.

2 Collateral is the new cash: the systemic risks of inhibiting collateral fluidity, 3 April 2014, https://www. icmagroup. org/ Regulatory-Policy-and-Market-Practice/repo-and-collateral-markets/erccpublications/icma-ercc-reports/collateral-fluidity/. 


\section{THE INDIRECT HOLDING SYSTEM AND NO LOOK THROUGH}

It is customary for investors today to hold their shares and bonds, not directly from the issuer, but rather through custodial intermediaries. This is primarily for reasons of operational efficiency.

Advantages for the investor of such intermediation include: the delegation of the administration and settlement of the securities; one-stop shopping for internationally issued portfolios; and access to the post trade infrastructure. Further, the pooling by intermediaries of the like securities of their respective clients reduces costs, enhances liquidity and facilitates timely settlement.

Multiple intermediaries are typically involved with international portfolios, and each intermediary performs a different function. For example, a UK life insurance company might hold its Erewhon bonds through a London global custodian (providing one-stop shopping for all its international investments). In turn, the global custodian holds these client assets through Euroclear (in Belgium) acting as International Central Securities Depository ("ICSD"), thereby facilitating settlements between international counterparties. Euroclear in its turn holds the relevant participant assets through an Erewhon common depository (acting for both Euroclear and Clearstream, the second EU-based ICSD). The use of a common depository provides access to the local treasury settlement system.

A comparable chain of title may be in place for each different category ${ }^{3}$ of investment, so that a complex sub-custodial network is involved.

The arrangement under which one or more intermediary stands in the chain of title between the issuer and the investors, and under which like client entitlements are held by the intermediary on a pooled basis, is commonly known as the Indirect Holding System.

\section{$2.1 \quad$ INTERESTS IN SECURITIES}

In the records of the issuer (or of the registrar or central securities depository ("CSD") acting on its behalf), the owner of record of the underlying shares or bonds is an intermediary. The only record of the investor's entitlement is in the books and records of the intermediary of which it is the direct client ("the Relevant Intermediary").

This entitlement relates, not to specific securities, but to a proportion of a pool of securities maintained by the Relevant Intermediary on behalf of multiple clients. It follows that the entitlement is in the nature of a co-ownership right or, alternatively, a fractional entitlement when the underlying asset is undivided.

The only record, and therefore the root of title, of this co-ownership right is the account of the Relevant Intermediary. It follows that this right is enforceable

3 I.e. different as to asset class and issue jurisdiction. 
in the jurisdiction where the Relevant Intermediary maintains the pooled client account.

Under certain EU measures relevant to the international financial markets, ${ }^{4}$ the law applicable to property rights concerning these entitlements is the law of the jurisdiction where the Relevant Intermediary maintains the account in favour of the investor. This rule follows the practicalities of enforcement, and in this respect accords with established principles of English conflict of laws. ${ }^{5}$

A distinction is therefore made between, on the one hand, the underlying securities (for which the root of title is the issuer register or CSD, typically in Erewhon, so that Erewhon law is lex situs), and the asset of the investor. The asset of the investor comprises, not the underlying securities, but interests in securities, reflected in the books and records of the Relevant Intermediary. The securities and the interests in securities are economically the same, but they are legally distinct.

\subsection{The No LoOK Through Principle}

Disadvantages for the investor of the indirect holding system include the principle, widely-accepted in Anglo-American jurisdictions, known as the No Look Through Principle. According to this principle, investors in intermediated securities do not under normal circumstances ${ }^{6}$ enjoy direct rights of action against the issuer, but must rely on the Relevant Intermediary to assert, or arrange for the assertion of, the rights associated with their holdings on their behalf.

\subsection{INTERMEDIARIES POOR ENFORCERS}

An important pinch point arises here. Intermediaries are poor enforcers of client entitlements, both in the normal course of business, and in contentious matters.

Intermediaries always agree to endeavour to pass cash and other assets generated by client securities on to clients. ${ }^{7}$ But nevertheless custodians typically build up significant pools of "orphan assets". These are cash and securities which the intermediary knows belong to clients, but does not know to which clients they belong. ${ }^{8}$

\footnotetext{
4 The Financial Collateral Directive 2002/47/EC article 9; Settlement Finality Directive 98/26/EC article 9(2); Recast Insolvency Regulation 2015/848 article 17; Winding Up Directive (Banks) 2001/24 art 24.

5 E.g. Cammell v Sewell (1860) 5 H \& N 728 at 1374; Winkworth v Christie [1980] 1 Ch 496 at 512.

6 A Deed of covenant may confer direct rights upon default of payment.

7 Such intermediaries may include paying agents.

8 This may be due to incomplete records, operational error and fractional entitlements.
} 
In relation to non-cash entitlements such as votes, the complexity of UK corporate actions culture is such that a significant level of error has historically occurred in the handling of client voting choices. ${ }^{9}$

In some circumstances, intermediaries may contractually limit their obligation to pass on votes and other non-cash entitlements. These circumstances include: where the client is not an active investor (e.g. some long/short hedge funds); where the underlying securities are in a jurisdiction or market that makes the exercise of entitlements operationally difficult; ${ }^{10}$ or where the intermediary's role is not full service, e.g. where it is the depositary in a DR program.

Intermediaries' enforcement track record is even poorer where the clients' claims are contentious. All intermediaries may hesitate to incur the unpredictable costs of litigation on a client's behalf, even where meaningful indemnities are in place. More fundamentally, the core client base of CSDs and ICSDs comprises issuers rather than investors. The conflict of interest inherent in investor requests to enforce contentious entitlements is typically resolved in favour of the issuer.

\subsection{SYSTEMIC RISK MANAGEMENT}

The case for the Indirect Holding System became clear in the aftermath of the "paper crunch" experienced in the 1987 market crash. At this time, settlement delays and backlogs occurred on a scale that threatened market stability. To address the risk of such disruption, the Indirect Holding System permits settlement in the name of the intermediary on behalf of investor clients, on an electronic and net basis. ${ }^{11}$ In some cases, settlement can be internalised by the intermediary. ${ }^{12}$ All of this radically increases settlement efficiency, not least because it radically reduces settlement volumes in the post trade infrastructure. The No Look Through Principle can thus be presented as an aspect of the collective commitment to the efficiency of that infrastructure.

More fundamentally, the Indirect Holding System assists the collateral taker. The fullest expression of the system was the 1994 Revision of Article 8 of the US Uniform Commercial Code on securities entitlements. Anecdotally, during the 1987 market crash, officers of the New York Fed asked the distinguished US law professor, Jim Rogers, whether collateral taken from broker dealers under emergency liquidity facilities was legally secure. His considered reply was, 'That's a good question'. Which was not good enough for the Fed. This led to the urgent development of a revised article 8 of the US Uniform Commercial Code, designed to provide legal certainty for investment securities held indirectly, and on a pooled and electronic basis.

\footnotetext{
9 It is understood that less error occurs today. In the past it was not uncommon for custodian banks to pay large sums of money to clients in compensation for relationship reasons and to avoid litigation. In the absence of litigation, the problem was under appreciated in the public domain.

10 E.g. where there are local restrictions on foreign ownership.

11 I.e. sell instructions from clients could be set against buy instructions from clients.

12 I.e. delivery made by debiting one client account and crediting another in the books of the intermediary.
} 
The revised article 8 came into effect in 1994. It defines the interest of the custody client recorded on the custodian's books as a "securities entitlement", distinct from the underlying securities, and provides clear rules for a range of issues including priorities. As reflected New York law, it offers a level of certainty for securities finance providers comparing favourably with that under other systems of law.

The key point is that the Indirect Holding System simplifies legal risk management for the collateral taker. In domestic law, property questions such as perfection and priority are conveniently determined by reference to the account of the Relevant Intermediary.

After the 1987 Big Bang, New York investment banks started practicing securities finance in London under English law, and over time they wanted a level of legal certainty comparable to that in New York. An era of International law reform effort began. The Hague Convention of 200613 ("Hague Convention") relates to choice of law rules and adopted as its primary rule a "party autonomy" approach, understood to be akin to that under the UCC, but in the end this did not find favour in the Europe. ${ }^{14}$ In cross border collateral arrangements, the EU approach to choice of laws has been for property questions to follow the account of the Relevant Intermediary under a choice of law rule known as the Place of the Relevant Intermediary Account (“PRIMA').15

This is the greatest gift of the Indirect Holding System to the collateral taker. As financial exposures are increasingly collateralised, and as collateral pools are increasingly internationally issued, the consolidation of the law applicable to property questions to a single jurisdiction, that of the Relevant Intermediary, is a central plank in legal risk management in securities finance. Given the very significant role of securities collateral in credit risk mitigation for central banks and systemically important financial institutions ("SIFIs"), the value of PRIMA is systemic. And PRIMA predicates No Look Through, because look through takes us back to the multiple jurisdictions of the issuers, fragmenting the legal aspects of the collateral pool.

However, if the No Look Through principle serves systemic risk management, it also runs directly counter to another public policy ambition, namely that of investor engagement.

\footnotetext{
${ }^{13}$ Hague Securities Convention on Securities Held with an Intermediary, http://www.hcch.net/upload/ conventions/txt36en.pdf.

${ }^{14}$ However, the convention has been ratified in the US, where it entered into force on 1.4.17. See https://www.hcch.net/en/instruments/conventions/status-table/?cid=72.

15 See footnote [3] above.
} 


\section{OPERATIONAL CHANGE AND THE SERVICE OF COLLATERAL TAKERS}

It was argued that the operational changes that serve the interests of collateral takers in the securities finance markets have been a disserve to investors. An extreme form of these changes was considered in one of the most interesting cases to come out of the failure of LBIE, namely the MCF litigation. ${ }^{16}$ As we know, tremendous client asset protection failures were experienced in that administration. It was argued before Briggs J., very broadly, that these operational arrangements were so inconsistent with the normal duties of the trustee to protect client assets as to be inconsistent with the existence of a trust. The clients' interests were pooled, subject to equivalent redelivery, ${ }^{17}$ rehypothecation, ${ }^{18}$ cash-out, ${ }^{19}$ blocking rights, 20 and close-out in default. ${ }^{21}$ While Mr Justice Briggs conceded that, 'it is a most unusual type of trust', ${ }^{22}$ he held that it was a trust nonetheless; as this was what had been agreed. ${ }^{23}$ The prime brokerage business plan involves hollowing out the rights of investors, by agreement and in exchange for very cheap credit. And it has judicial support. None of the extensive litigation following the failure of LBIE disturbed the Indirect Holding System, even in its most developed form.

\section{INVESTOR ENGAGEMENT}

Of course this comes at a cost. A prevailing ambition for the capital markets is to increase the engagement of investors with their investee companies in the interests of effective corporate governance.

16 In re LBIE [2009] EWHC 2545.

${ }^{17}$ LBIE as custodian was obliged to deliver up securities equivalent to those received from or for the client (i.e. same number, same type), but not the same ones.

${ }_{18}$ Rehypothecation is the contractually permitted practice of the prime broker transferring client securities from client account to house account, and thence using them for any purpose and for its own account, subject to equivalent redelivery obligations upon client demand to close the rehypothecation.

${ }_{19}$ Where it is not possible for the prime broker to locate and provide equivalent securities in time to meet a client demand to close the rehypothecation, it is contractually entitled to close by paying the current market value of the rehypothecated securities.

20 The prime broker is contractually entitled to prevent the client from removing securities from the prime broker's client account (where they are subject to the prime brokers' charge) if the result of such removal would or might be to leave the prime broker under collateralised.

${ }^{21}$ Upon default, the cross obligations of the parties (including the property rights of the client in the custody securities) are valued, non-cash claims are converted to cash claims and set off against each other, so that only a net sum is payable.

22 At para. 52.

23 Para. 53. 


\subsection{STEWARDSHIP}

Greater shareholder activism, particularly through voting, is a theme of the 2001 Myners Review of Institutional Investment in the UK. ${ }^{24}$

A central lament of the 2012 Kay Review of UK Equity Markets and Long-Term Decision Making 25 is of short-termism in the UK equity markets. Ten Kay Review Principles are set out, including (in Principle three) a call for greater investor engagement, ${ }^{26}$ long-term goals and the development of shareholding into stewardship of the investee company.

The UK Stewardship Code of $2012^{27}$ encourages institutional investors to take an active governance role in UK Plcs, through voting and otherwise, and to disclose their stewardship activities and policies on a "comply or explain" basis. Principle 6 provides that '[i]nstitutional investors should have a clear policy on voting and disclosure of voting activity'. Guidance includes that '[i]nstitutional investors should seek to vote all shares held. ${ }^{28}$

The policy ambition is that shareholders should be gatekeepers, ${ }^{29}$ and help deliver the long-term decision-making and responsible capitalism that we want, and the need for which became very clear with the 2008 financial crisis.

\subsection{STEWARDSHIP VERSUS INTERMEDIATION}

In its 2014 paper, Fiduciary duties of Investment Intermediaries, 30 The Law Commission comments that, while the Indirect Holding System offers operational advantages to the investor, ${ }^{31}$ it also introduces risks. As well as the risk of fraud, '[it] also makes it more difficult for investors to exercise their voting rights, which discourages stewardship activities. ${ }^{32}$

\footnotetext{
${ }^{24}$ See http://webarchive.nationalarchives.gov.uk/20130129110402/http:/www.hm-treasury.gov.uk/ media /2F9/02/31.pdf. See pp. 14, 89 - 93, 199.

25 July 2012, https://www.gov.uk/government/uploads/system/uploads/attachment_data/file/253454/ bis-12-917-kay-review-of-equity-markets-final-report.pdf.

26 'Asset managers can contribute more to the performance of British business (and in consequence to overall returns to their savers) through greater involvement with the companies in which they invest.' P. 12.

${ }^{27}$ See https://www.frc.org.uk/Our-Work/Publications/Corporate-Governance/UK-Stewardship-CodeSeptember-2012.pdf.

28 P. 9

${ }^{29}$ John Coffee, Gatekeepers: The Professions and Corporate Governance, Oxford University Press, 2006.

30 See http://www.lawcom.gov.uk/wp-content/uploads/2015/03/lc350_fiduciary_duties.pdf.

31 P. 236:

Intermediation offers practical advantages to both issuers and investors. Recording investors' interests in securities electronically in the computerised accounts of an intermediary allows for greater transferability, which in turn enhances liquidity and consequently the value of the securities. It is also administratively convenient: an investor can hold their entire international portfolio through a single intermediary, without having to bear the administrative burden of establishing and maintaining links with issuers and other intermediaries in different settlement systems.

32 P. 236.
} 
A more severe approach to intermediaries is taken in the Kay Review. Its answer to the conflict between intermediation and engagement is to abolish the former. (The Review addresses a range of non-custodial intermediaries, ${ }^{33}$ but its comments on intermediation also hold good for the custodial intermediaries considered in this discussion.)

It notes that intermediation is relatively recent, ${ }^{34}$ and associated with both computerisation ${ }^{35}$ and institutional investment. ${ }^{36}$ Intermediation introduces costs and conflicts of interest, ${ }^{37}$ and is a factor contributing to the decline of investor engagement. ${ }^{38}$ Thus, ' $[t]$ he chain of intermediation should be shortened. ${ }^{39}$

Seventeen Kay Review Recommendations are made, the final one of which plainly targets the antagonism between intermediation and engagement: 'The Government should explore the most cost effective means for individual investors to hold shares directly on an electronic register.' 40

\section{LAW REFORM}

Three major law reform initiatives have sought to address (among other things) the rights of the investor in indirectly held securities. These are: on choice of law (internationally), the Hague Convention; ${ }^{41}$ on substantive law rules (internationally), the Geneva Securities Convention; ${ }^{42}$ and generally (in the EU),

33 'Between the company and the saver are now interposed registrars, nominees, custodians, asset managers, managers who allocate funds to specialist asset managers, trustees, investment consultants, agents who 'wrap' products, retail platforms, distributors and independent financial advisers.' P. 30.

34 'Fifty years ago, most shares in UK companies were owned by individuals. ... When individual shareholding was the norm, shareholders would receive communications directly from the companies in which they invested.' P. 29.

35 'With the introduction of electronic trading in the 1990 s, retail investors were encouraged to hold shares in nominee account maintained by the principal banks and private client stockbrokers.' P. 29. 36 'The decline in the role of the individual shareholder has been paralleled by an explosion of intermediation.' P. 30 .

37 P. 30:

Whether the reasons for the proliferation of intermediation and intermediaries are good or bad, such proliferation adds to the costs of the investment chain, and creates potential for misalignment of incentives at each link of the chain. ... A by-product of the growth of intermediation has been a tendency to view the performance of the market through the eyes of intermediaries. ... Goals such as liquidity, transparency, and price disco very have come to be regarded as ends in themselves, and not as intermediate steps towards the underlying objectives of high performing companies and good returns for savers.

See also 35: 'the more extended is the chain of intermediaries, the more scope there is for such misalignment of incentives.'

38 'The structure of the industry favours exit over voice...'. P. 42.

39 P. 46.

40 P. 13.

41 See footnote [9] above.

42 UNIDROIT Convention on Substantive Rules Regarding Intermediated Securities, 2009, http://www.unidroit.org/meetings/103-instruments/capital-markets/capital-markets-genevaconvention/178-unidroit-convention-on-substantive-rules-for-intermediated-securities-geneva-2009. 
the proposal for Securities Law Legislation. ${ }^{43}$ At least in their original conception, each of these has favoured the collateral taker.

All these projects have stalled following the polarisation of opinion and the politicisation of the debate. In the past I have understood the failure of these projects to come to fruition as stemming from cultural differences between civilians and common lawyers. On reflection, the heart of the matter is more specific. If we are playing a zero sum game between investors and collateral takers, consensus will continue to elude us.

\section{CASE LAW}

Recent case law has confirmed the no look through principle, on the basis that the investor is not the holder of the underlying securities

\subsection{ECKERLE (2014)}

The 2014 case of Eckerle 44 is authority that investors in intermediated shares are not shareholders for the Companies Act purposes. The case related to the shares of a UK plc (DNick). DNick was managed and operated from Germany, its shares were listed only in Germany, and held in dematerialised form by a custodian (BNY) for the account of participants in Clearstream. Investors beneficially owning over $5 \%$ of the shares objected to a proposed delisting and reregistration as a private company, and sought to block the reregistration under section 98 of the Companies Act 2006.

It was held that the investor claimants could not benefit from these minority shareholder protections, as they were not shareholders for Companies Act purposes. Their asset comprised, not shares in DNick, but rather "Clearstream Interests" ("CIs"). ${ }^{45}$ Indeed, "what is actually traded on Deutsche Börse are not the shares of DNick but CIs (representing the underlying ownership rights in DNick shares."46 "Shareholder" for this purpose meant a person whose name is entered on the register of members of the issuer. ${ }^{47}$ "The literal truth is that the Claimants hold the ultimate economic interest in underlying securities amounting to a specified percentage of the shares held by BNY on trust for Clearstream account holders whose customers the Claimants are.'48

${ }^{43}$ See http://ec.europa.eu/finance/consultations/2010/securities/index_en.htm.

44 Eckerle v Wickeder [2013] EWHC 68 (Ch).

45 Per Norris J, para. 14.

46 Ibid.

47 "So a "shareholder" or "the holder of a share" (the terms are interchangeable) is one (and only one)

whose name is registered in the register of members.' Para. 18.

48 Para. 14. 
Whereas Eckerle related to equity, Secure Capital (2015) ${ }^{49}$ relates to debt securities. Under the bonds in question, the payment obligation of the issuer depended on the mortality rates of holders of reference life policies. The bonds were issued in global form and held through Clearstream. BNY as common depository held the bonds for Clearstream, which in turn held its interest for participants. Secure Capital held its interest through a custodian (RBS Luxembourg) which was a Clearstream participant. (Thus, whereas Eckerle involved two levels of intermediation, Secure Capital involved three.)

The terms of issue included a contractual "no look through" provision. ${ }^{50}$ The issue documents contained a responsibility statement by Credit Suisse, that it had taken all reasonable care to ensure that the information provided was accurate and that there were no material facts the omission of which would make any statement contained in the documentation misleading ("misleading statement term"). But the issue document omitted to state that the mortality tables used to estimate life expectancies was about to be updated, so as to increase estimated life expectancies, rendering the bonds worthless. Secure Capital brought a claim for breach of the misleading statement term.

Secure Capital argued that it had a direct right of action against Credit Suisse under Luxembourg Law. However, Mr Justice Hamblen found for Credit Suisse, and also for the Indirect Holding System, noting that " $[\mathrm{r}]$ ights in relation to securities are traded electronically between members who have accounts with Clearstream, rather than the securities themselves. ${ }^{51}$ Secure Capital was not a bondholder, and had no locus standi. Although Luxembourg law provided for a direct right of action against the issuer, Luxembourg law was not relevant to the issue before the court. While PRIMA (together with so much published discussion on choice of law in indirectly held securities) turns on the property questions dear to the collateral taker, this case was not about property. The question of liability under the misleading statement term was a contractual matter, to which the law applicable was that governing the terms of issue, i.e. English law.

\section{$7 \quad$ RECOMMENDATIONS}

In order to accommodate both investors and collateral takers, it is recommended that two distinct classes of securities should be issued. These might be called,

\footnotetext{
49 Secure Capital SA v Credit Suisse AG [2015] EWHC 388 (Comm), awaiting appeal.

50 'Each person shown in the records of Clearstream must look solely to Clearstream "for his share of each payment made by the Bank and in relation to all other rights arising under the Global Securities, subject to and in accordance with the respective rules and procedures of"... Clearstream'. This provision is sometimes called the "no look through" provision. Para. 15(5).

51 Para. 22(1).
} 
traditional securities and collateral depositary receipts ("CDRs") respectively. Consistently with this, two distinct client asset regimes should be in place. ${ }^{52}$

Traditional securities would comprise shares and bonds issued in definitive form. ${ }^{53}$ Client asset regulation would require the intermediary to offer the option of individual client segregation (much as now under EMIR ${ }^{54}$ and CSDR) 55 and also the full exercise of client entitlements. These traditional securities would not (without more) be available for securities finance, and would not be subject to the operational arrangements, discussed above, that facilitate it.

This might be achieved through custodial intermediation, as is normal now, or by conferring on clients direct legal title, possibly through blockchain software, and possibly on a legal basis akin to CREST ${ }^{56}$ sponsored membership, with the intermediary acting as agent but not as trustee. In any case, it would be consistent with long-term, buy-to-hold, active investment.

In contrast, for collateral takers (including sophisticated investors wishing to become collateral takers in whole or in part), a depositary receipt program could be introduced. Underlying securities would be held by an intermediary as trustee on a pooled basis. The intermediary would be permitted to limit contractually client entitlements. These CDRs could be subject to all the operational arrangements facilitating liquidity. As with other DR programs, the underlying traditional securities could be brought freely into and out of the CDR structure.

To take a lesson from history, before the development of modern banking the best way to protect depositors would have been to order banks to keep deposited money in their safes. But this is not what happened. Pragmatically, if we are serious about success in re-enfranchising investors, we would be wise to step out of the way of the Juggernaut of capitalism on the move.

52 See J. Benjamin, "The Lessons of LBIE Reuse and Rehypothecation" in Faber and Vermunt, Bank

Failure: Lessons from Lehman Brothers, OUP, Oxford 2017.

53 Bonds in definitive form are the traditional bearer debt instruments in paper form.

${ }^{54}$ European Market Infrastructure Regulation, EU Regulation 648/2012.

55 Central Securities Depositories Regulation, EU Regulation 909/2014.

56 The UK settlement system. 